\title{
ANALYSIS OF CATHETER-ASSOCIATED INFECTIONS IN CHILDREN NEEDING INTENSIVE THERAPY
}

\section{АНАЛІЗ КАТЕТЕР-АСОЦІЙОВАНИХ ІНФЕКЦІЙ У ДІТЕЙ, ЩО ПОТРЕБУЮТЬ ІНТЕНСИВНОЇ ТЕРАПІЇ}

\author{
Jaroslav Pidhirnyy ${ }^{1}$ \\ Zoryana Sadova-Chuba ${ }^{2}$
}

DOI: https://doi.org/10.30525/978-9934-588-15-0-70

Abstract. Urinary infections are a leading group of nosocomial infections accounting for $40 \%$ of hospital-acquired infections. Approximately $80 \%$ of these are related to urinary catheters. We have analysed 98 patients treated at Intensive Care of Lviv Regional Pediatric Clinical Hospital aged 1-18 years. Group 1 included 49 children with septic surgical conditions, who underwent bladder catheterization at the operating room. Group 2 included 49 children with medical conditions who underwent catheterization in the ICU. All patients received broad spectrum antibiotics for their underlying conditions. Patients with urinary system pathologies were excluded. Catheter-associated urinary infections (CAUI) were diagnosed based on bacteriuria $\geq 105 \mathrm{CFU} / \mathrm{mL}$. Quality of life was tested using the adapted Pediatric Quality of Life Inventory 2014 for children aged 8-12 years. Study objective: to improve the outcomes in children with nosocomial urinary infections through better understanding of pathogenesis, better diagnostic criteria, prevention and treatment. Positive cultures in group 1 comprised $35 \%$ of all positive cultures, vs. $63 \%$ in group 2 . From most cultures $(85.42 \%)$ positive for CAUI only one pathogen was isolated. The following agents were identified as the cause of CAUI: Escherichia coli, Klebsiella pneumoniae, Enterococcus spp., Pseudomonas aeruginosa, Candida albicans, Staphylococcus epidermidis. There was no statistically significant difference in etiology between the surgical and medical patients in the

\footnotetext{
${ }^{1}$ Doctor of Medical Sciences, Professor,

Head of the Department of Anesthesiology and Intensive Care D. Halytsky, Lviv National Mediical University, Ukraine

${ }^{2}$ Assistant of the Department of Anesthesiology and Intensive Care D. Halytsky,

Lviv National Mediical University, Ukraine

(C) Jaroslav Pidhirnyy, Zoryana Sadova-Chuba
} 
ICU. In group 1 the incidence of CAUI on day 3 post catheterization was $18,37 \%$, while in group 2 it was $36,73 \%, p=0,04$. The incidence of CAUI on day 5 post catheterization was $36.73 \%$ in group 1 and $61.22 \%$ in group 2 , $\mathrm{p}=0,02$. Patients undergoing catheterization in the operating room develop urinary infections less frequently and less rapidly than those catheterized in the ICU. We believe that initiation of antibacterial treatment for catheter associated urinary infection before the 3 rd day post catheterization and prior to obtaining positive culture result is unjustified and worsens the antibiotic resistance in the ICU. Quality of life of children with urinary catheters is affected by psychological trauma and discomfort more than by the scope and number of medical interventions, as shown by mental function points being significantly lower than the physical function points.

\section{1. Вступ}

Нозокоміальні інфекції - серйозна медико-соціальна, економічна та юридична проблема у відділеннях інтенсивної терапії (BIT) усього світу, частота їх розвитку залежить від профілю та архітектурно-технічних особливостей відділення, а також від адекватності програми інфекційного контролю і складає в середньому 11\%. Поширення інфекційних ускладнень у пацієнтів ВІТ суттєво підвищує смертність, збільшує терміни та вартість лікування [1, р. 208].

Інтенсивний розвиток високотехнологічних, інвазивних методів діагностики та лікування, у поєднанні з поширеністю полірезистентних мікроорганізмів, визначає необхідність безперервного вдосконалення системи мікробіологічного моніторингу та епіднагляду за цією групою інфекцій.

У ВІТ в середньому поступає лише 5-10\% хворих стаціонару, проте, частка виникнення нозокоміальних інфекцій у них складає 20-25\%. Слід відзначити, що частота розвитку інфекцій залежить від типу ВІТ (терапевтичне, хірургічне, серцево-судинне), а також особливостей пацієнтів (вік, супутні захворювання). У великих міських стаціонарах частота розвитку нозокоміальних інфекцій, зазвичай вища, у порівнянні з невеликими лікарнями [2, p. 1495].

Інфекції сечових шляхів (ICШ) - це одна з найпоширеніших нозокоміальних інфекцій. Більш ніж у 80\% пацієнтів, у яких підчас госпіталізації виникли прояви інфекції сечових шляхів, мала місце тривала 
катетеризація сечового міхура. Кожен третій пацієнт ВIT, який перебуває у відділенні більше 3 днів та має сечовий катетер, має ті або інші ознаки запалення сечових шляхів [3, p. 744].

Більшості пацієнтам 3 внутрішньолікарняними інфекціями сечової системи (ВЛІСС) виконувались інструментальні маніпуляції на сечовій системі (10-20\%) i/або катетеризація сечового міхура (80\%), основна частина ВЛІСС є катетер-асоційованими (74\%) [4, p. 1168].

За даними літератури, одноразова катетеризація сечових шляхів стає причиною ICШ у 1-5\% випадків. Постійний сечовий катетер, що стоїть довше чотирьох діб з відкритою дренажною системою стає причиною ІСШ у 100\%. Слід відзначити, що за даними багатьох авторів, перехресне інфікування у стаціонарі відбувається більш ніж у 40\% пацієнтів котрим був катетеризований сечовий міхур [5, p. 76].

Незважаючи на прогрес в галузі інфекційного контролю, появу та впровадження у практику нових антимікробних препаратів, вдосконалення методів діагностики, покращення загального догляду за хворими, проблема профілактики та контролю нозокоміальних інфекцій залишається актуальною.

Мета даного дослідження: покращити результати лікування хворих 3 нозокоміальною інфекцією сечовидільних шляхів, через уточнення ланок її патогенезу, удосконалення критеріїв діагностики, методів профілактики та лікування.

Нами обстежено 98 пацієнтів, що лікувались у відділені інтенсивної терапії КНП ЛОДКЛ «ОХМАТДИТ» віком 1-18. Усіх пацієнтів поділено на дві групи. Групу 1 становили пацієнти з гнійною хірургічною патологією (перитоніт, остеомієліт) кількістю 49 дітей, катетеризація сечового міхура пацієнтам цієї групи проводилась в умовах операційної. Групу 2 становили пацієнти 3 соматичною патологією (пневмонія, вроджені вади розвитку серцево-судинної системи, вроджені вади розвитку нервової системи) кількістю 49 дітей, катетеризація сечового міхура пацієнтам цієї групи проводилась в умовах відділення інтенсивної терапії.

Всі пацієнти отримували антибіотикотерапію препаратами широкого спектру дії, з приводу основного захворювання.

Критерієм виключення, була наявність у пацієнтів патології сечостатевої системи. 
Використовували катетер Фолея, при встановленні дотримуючись правил постановки катетера і асептики зокрема, дренажна система закритого типу. Згідно даних національної мережі безпеки охорони здоров'я США (NHSN), наявність сечового катетера понад 2 дні, гарячка і бактеріоурія, є достатніми підставами для діагностики катетер-асоційованої інфекції сечових шляхів. Оскільки всі нами набрані пацієнти на грунті основного захворювання мали ті чи інші ознаки запального процесу, то основним критерієм діагностики КАІСШ була бактеріоурія $\geq 10^{5}$ КУО/мл $[1 ; 2 ; 3]$.

Дослідження біологічного матеріалу та інтерпретацію отриманих результатів проводили згідно з наказом МОЗ СРСР № 535 від 22.04.1985 р. «Об унификации микробиологических (бактериологических) методов исследования, применяемых в клинико-диагностических лабораториях лечебно-профилактических учреждений». Ідентифікацію виділених мікроорганізмів проводили загальноприйнятим бактеріологічним методом, дотримуючись класифікації Бергі (1997). Чутливість виділених штамів мікроорганізмів до антибіотиків вивчали згідно з наказом МОЗ України № 167 від 05.04.2007 р. «Про затвердження методичних вказівок «Вивчення чутливості мікроорганізмів до антибактеріальних препаратів». Мікробіологічний посів сечі проводили на третій та п'ятий день перебування пацієнта у ВIT, також проводили мікробіологічний посів 3 кінчика сечового катетера, після його видалення.

Статистичну обробку матеріалу проводили за допомогою програми "Statistica for Windows 10.0" (Statsoft, USA) методами варіаційної статистики. Для цього було створено базу даних в редакторі Google Sheets. Різницю між порівнюваними величинами вважали вірогідною при $\mathrm{p}<0.05$.

\section{2. Аналіз етіологічної структури КАІСШ}

У $15-20 \%$ пацієнтів госпіталізованих у стаціонар хірургічного профілю виникає потреба катетеризації сечового міхура, у 15-30\% 3 них розвивається бактеріоурія. Пацієнти з уретральним катетером мають схильність до розвитку ускладнених інфекцій сечовидільних шляхів, навіть при використанні закритих дренажних систем. Дещо менш гостро стоїть питання інфекцій сечових шляхів у пацієнтів з цистосто- 
мічними і нефростомічними дренажними трубками, але і в них розвиток ІСШ питання лише часу. За останніми даними, ризик виникнення ICШ на фоні уретрального катетера зростає на 4-7,5\% в день [6, p. 105].

Загальна кількість позитивних посівів 1 групи складала 20, що становить $35 \%$ від усіх 3 позитивним посівом; у 2-й групі хворих, що мали позитивний посів було отримано у 35 пацієнтів.

У 41 пацієнта мала місце монокультура $(85,42 \%$ від пацієнтів 3 позитивним мікробіологічним посівом сечі), у 7 пацієнтів мала місце мікробіологічна асоціація (14,58\% відповідно).

Результати дослідження етіологічної структури збудників катетер-асоційованих інфекцій сечових шляхів у дітей, що потребують інтенсивної терапії, показав наступний видовий склад мікроорганізмів: Escherichia coli висіялась у 6 випадках, Klebsiella pneumoniae у 9 випадках, Enterococcus spp. - у 7 випадках, Pseudomonas aeruginosa у 11, Candida albicans - у 20, Staphylococcus epidermidis - у 2 пацієнтів (табл. 1).

Таблиця 1

Етіологічна структура катетер-асоційованих інфекцій у відділенні інтенсивної терапії дитячої клініки (n=48)

\begin{tabular}{|l|c|c|}
\hline \multicolumn{1}{|c|}{ Вид мікрооргаізму } & Частота виділення мікроорганізму \\
\hline & Абс. & Відсотки \\
\hline Escherichia coli & 6 & $10.91 \%$ \\
\hline Klebsiella pneumoniae & 9 & $16.36 \%$ \\
\hline Enterococcus spp. & 7 & $12.73 \%$ \\
\hline Pseudomonas aeruginosa & 11 & $20.00 \%$ \\
\hline Candida albicans & 20 & $36.36 \%$ \\
\hline Staphylococcus epidermidis & 2 & $3.64 \%$ \\
\hline
\end{tabular}

Кількість випадків отриманої монокультури у 1 групі становила 16, у 2 групі становило 25. Кількість отриманих мікробіологічних асоціацій у 1 групі становило 2 випадки, у 2 групі - 5 випадків. Відповідно, кількість позитивних посівів 3 монокультурою у першій групі становило 33,3\%, у 2 групі позитивний посів з монокультурою отримано у $52,08 \%$. Мікробіологічні асоціації у першій групі становили 4,17\%, а у другій групі мікробіологічні асоціації становили 10,42\%. 
В 1 групі Escherichia coli мала частку 3,64\%, Klebsiella pneumoniae 5,45\%, Enterococcus spp. 5,45\%, Pseudomonas aeruginosa 7,27\%, Candida albicans мала найбільшу частку $12,73 \%$, Staphylococcus epidermidis 1,82\%. В 2 групі найбільшу частку мали Pseudomonas aeruginosa $12,73 \%$ i Candida albicans 23,64\%, менші частки були у Escherichia coli 7,27\%, Klebsiella pneumoniae 10,91\% та Enterococcus spp. 7,27\%,\%, найменша частка була у Staphylococcus epidermidis 1,82\% (табл. 2).

Таблиця 2

Етіологічна структура катетер-асоційованих інфекцій хірургічних та соматичних паціснтів, що потребують інтенсивної терапії

\begin{tabular}{|c|c|c|c|c|}
\hline \multirow{2}{*}{ Вид мікроорганізму } & \multicolumn{2}{|c|}{$\begin{array}{c}\text { Група } 1 \text { (хірургічні) } \\
\text { n=18 }\end{array}$} & \multicolumn{2}{|c|}{$\begin{array}{c}\text { Група } 2 \text { (соматичні) } \\
\text { n=30 }\end{array}$} \\
\hline & Абс. & Відсотки & Абс. & Відсотки \\
\hline Escherichia coli & 2 & $3.64 \%$ & 4 & $7.27 \%$ \\
\hline Klebsiella pneumoniae & 3 & $5.45 \%$ & 6 & $10.91 \%$ \\
\hline Enterococcus spp. & 3 & $5.45 \%$ & 4 & $7.27 \%$ \\
\hline Pseudomonas aeruginosa & 4 & $7.27 \%$ & 7 & $12.73 \%$ \\
\hline Candida albicans & 7 & $12.73 \%$ & 13 & $23.64 \%$ \\
\hline Staphylococcus epidermidis & 1 & $1.82 \%$ & 1 & $1.82 \%$ \\
\hline
\end{tabular}

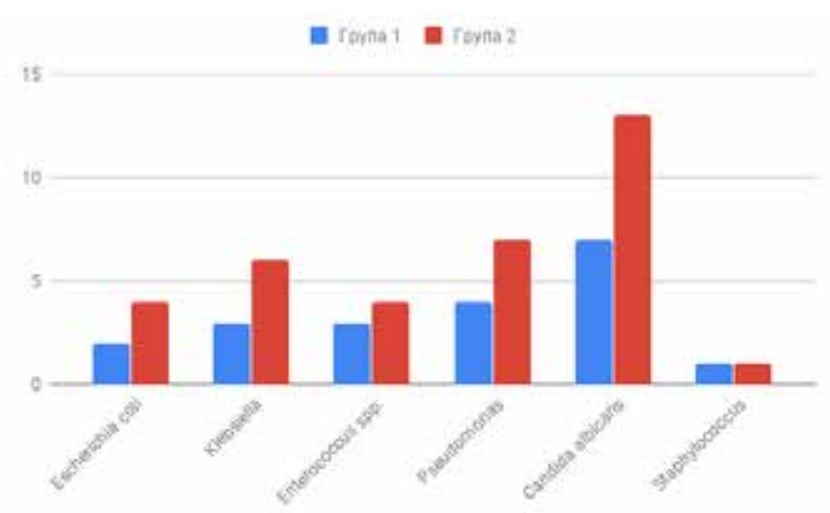

Рис. 1. Структура збудників катетер-асоційованих інфекцій у соматичних та хірургічних пацієнтів, що потребують інтенсивної терапії 
Якщо отримані дані з таблиці 2 перенести у діаграму, то помітно, що кількість отриманих позитивних посівів суттєво більша у групі 2, у порівнянні 3 групою 1. Найчастіше виявили Candida albicans: 7 у першій групі, 13 у другій групі. Серед грамнегативних бактерій як у 1 групі так і у 2 групі переважає Pseudomonas aeruginosa, та Klebsiella pneumoniae - 6. Серед грампозитивних бактерій переважала Enterococcus spp.: у 1 групі 3 випадки, у 2 групі - 4. Як у першій так і у другій групі досліджуваних мав місце один випадок позитивного посіву з Staphylococcus epidermidis (рис. 1).

\section{3. Антибіотикорезистентність основних збудників КАІСШ}

Проаналізувавши антибіотикорезистентність отриманих нами грампозитивнх збудників ми побачили, що Enterococcus spp найбільш резистентний до цефтазидиму, кліндаміцину, левофлоксацину та цефтріаксону, також висока резистентність до меронему, цефепіму, цефотаксиму, ципрофлоксацину, гентаміцину. Повну резистентність Staphylococcus epidermidis проявив до кліндаміцину, у половини випідках чутливим був до цефтазидиму, цефтріаксону, цефотаксиму, моксифлоксацину, ципрофлоксацину, левофлоксацину. Амікацину, гентаміцину (табл. 3).

Якщо отримані результати по антибіотикочутливості перенести у діаграму, то помітно, що Enterococcus spp. найменш резистентна до імепенему - 14,28\% та амікацину - 28,57\% та повністю відсутня антибіотикорезистентність (стійкість) до ванкоміцину та тейкопланіну. У отриманих нами штамів Staphylococcus epidermidis повністю відсутня антибіотикорезистентність до ванкоміцину, тейкопланіну, імепенему, меронему (рис. 2).

Серед отриманих нами грамнегативних збудників Pseudomonas aeruginosa найбільшу антибіотикорезистентність мала до цефтріаксону - 90,91\%, моксифлоксацину та гентаміцину - 81,81\% цефоперазону та цефотаксиму - 72,73\%, стовідсоткову антибіотикорезистентність до кліндаміцину та оксациліну. Антибіотикорезистентність Klebsiella pneumonia була високою до гентаміцину $-77,78 \%$, кліндаміцину - 90\%, оксациліну - 97\%. Помірну атибіотикорезистентність отриманий нами штам Klebsiella pneumonia мав до цефепіму - 66,67\%, цефопіразону та цефатоксиму - 66,67\%. Отриманий нами штам Escherichia coli проявив високу антибіотикорезистентність (стійкість) 
Таблиця 3

Антибіотикорезистентність грампозитивних збудників катетер-асоційованих інфекцій у дітей, що потребують інтенсивної терапії у \% $(n=48)$

\begin{tabular}{|l|c|c|}
\hline \multirow{2}{*}{$\begin{array}{c}\text { Антимікробний } \\
\text { препарат }\end{array}$} & \multicolumn{2}{|c|}{ Вид мікроорганізмів } \\
\cline { 2 - 3 } & $\begin{array}{c}\text { Staphylococcus } \\
\text { epidermidis }\end{array}$ & Enterococcus spp. \\
\hline Іміпенем & 0 & 14,28 \\
\hline Меропенем & 0 & 71,43 \\
\hline Цефепім & 0 & 71,43 \\
\hline Цефтазидим & 50 & 85,71 \\
\hline Цефтріаксон & 50 & 85,71 \\
\hline Цефопіразон & 50 & 57,14 \\
\hline Цефотаксим & 50 & 71,43 \\
\hline Моксифлоксацин & 50 & 57,14 \\
\hline Ципрофлоксацин & 50 & 71,43 \\
\hline Левофлоксацин & 50 & 85,71 \\
\hline Амікацин & 50 & 28,57 \\
\hline Гентаміцин & 50 & 71,43 \\
\hline Кліндаміцин & 100 & 85,71 \\
\hline Оксацилін & 50 & 85,71 \\
\hline Ванкоміцин & 0 & 0 \\
\hline Тейкопланін & 0 & \\
\hline
\end{tabular}

до моксифлоксацину - 83,33\%, цефопіразону та левофлоксацину $66,66 \%$, кліндаміцину - 90\% (табл. 4).

Якщо отримані нами дані по антибіотикорезистентності грамнегативних мікроорганізмів перенести у діаграму, то помітно, що найменшу резистентність Pseudomonas aeruginosa має до імепенему та меронему 9,09\%, амікацину - 18,18\%, цефепіму - 27,27\%, цефтазидиму - 36,36\%. Отримані нами штами Klebsiella pneumonia найменш антибіотикорезистентними (стійкими) були до імепенему та меронему - 11,11\%, амікацину - 22,22\%, левофлоксацину - 33,33\%, цефтріаксону та ципрофлоксацину - 44,44\%. Найбільш чутливим отриманий нами штам Escherichia coli був до імепенему, меронему та амікіцину, висока чутливість спостерігалась до ципрофлоксацину та цефтазидиму - 33,33\% (рис. 3 ).

Усі виділені штами C. albicans були чутливими у $45 \%$ до клотрімазолу. 
120

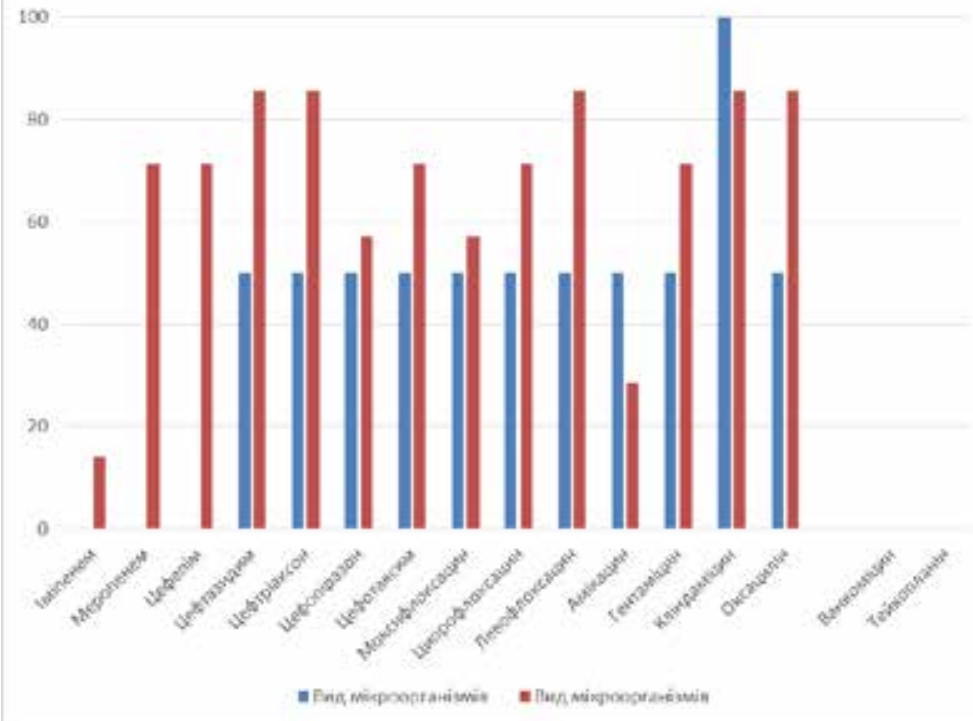

Рис. 2. Антибіотикорезистентність грампозитивних збудників КАІСШ у ВІТ дитячої клініки, \%

\section{4. Профілактика КАІСШ}

Ризик виникнення КАІСШ залежить від методу й тривалості катетеризації, якості догляду за катетером і сприйнятливості організму.

Використання закритої дренажної системи, у тому числі з клапаном, значно знижує ризик розвитку КАІСШ, хоча він усе ще залишається значним. Останні дослідження показали, що більше $20 \%$ пацієнтів може бути інфіковано в лікарняних палатах навіть при використанні закритої дренажної системи [8, р. 150]. У цих дослідженнях відзначено, що помилки, які часто зустрічаються при використанні стерильного закритого сечового дренажу, були причиною інфікування пацієнтів. Фактори пацієнта, що збільшують ризик розвитку катетер-асоційованої інфекції сечових шляхів включають: літній вік, стан імуносупресії, післяпологовий та післяопераційний стани [7, p. 186]. 
Таблиця 4

Антибіотикорезистентність грамнегативних збудників катетер-асоційованих інфекцій сечових шляхів у дітей, що потребують інтенсивної терапії КАІСШ, \% $(n=48)$

\begin{tabular}{|l|c|c|c|}
\hline \multirow{2}{*}{$\begin{array}{c}\text { Антимікробний } \\
\text { препарат }\end{array}$} & \multicolumn{3}{|c|}{ Вид мікроорганізмів } \\
\cline { 2 - 4 } & Escherichia coli & $\begin{array}{c}\text { Klebsiella } \\
\text { pneumonia }\end{array}$ & $\begin{array}{c}\text { Pseudomonas } \\
\text { aeruginosa }\end{array}$ \\
\hline Іміпенем & 0 & 11,11 & 9,09 \\
\hline Меропенем & 0 & 11,11 & 9,09 \\
\hline Цефепім & 50 & 66,67 & 27,27 \\
\hline Цефтазидим & 33,33 & 55,56 & 36,36 \\
\hline Цефтріаксон & 60 & 44,44 & 90,91 \\
\hline Цефопіразон & 66,66 & 66,67 & 72,73 \\
\hline Цефотаксим & 50 & 66,67 & 72,73 \\
\hline Моксифлоксацин & 83,33 & 55,56 & 81,81 \\
\hline Ципрофлоксацин & 33,33 & 44,44 & 63,64 \\
\hline Левофлоксацин & 66,66 & 33,33 & 18,18 \\
\hline Амікацин & 0 & 22,22 & 81,82 \\
\hline Гентаміцин & 50 & 77,78 & 100 \\
\hline Кліндаміцин & 90 & 90 & 100 \\
\hline Оксацилін & 100 & 97 & \\
\hline
\end{tabular}

Наявність сечового катетера відкриває доступ мікроорганізмам у сечовий міхур. Свропейська асоціація урологів (2008) виділила нижченаведені фактори ризику КАІСШ:

- колонізація мікробами сечоприймача, катетера, периуретрального простору;

- цукровий діабет;

- жіноча стать;

- ниркова недостатність;

- неадекватний догляд за катетером, включно з постановкою його за межами операційної;

- неадекватна антибіотикотерапія.

Як показали результати проведеного нами дослідження частота виникнення катетер-асоційованої інфекції у групі 1 на третій день $\epsilon$ нижчою, ніж у групі 2 , і становить $18,37 \%$, у посіві сечі, зібраній для мікробіологічного дослідження, цей показник становив $36,73 \%$. 


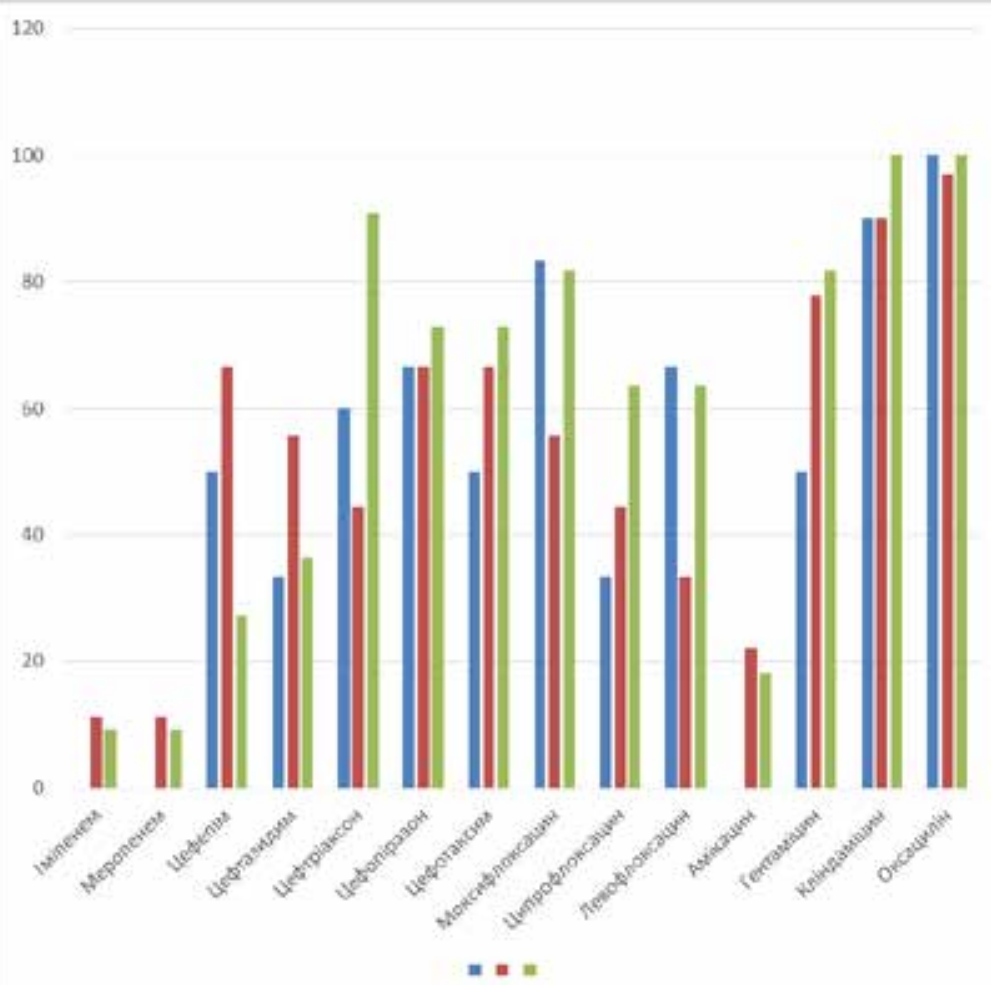

Рис. 3. Антибіотикорезистентність грамнегативних збудників КАІСШ у ВІТ дитячої клініки (\%)

У 2 групі відсоток позитивного мікробіологічного посіву на третій день становив 36,73\%, а на 5-й день відсоток був суттєво вищим, ніж у 1 групі і становив 61,22\% (табл. 5).

Результати можна вважати достовірними, оскільки, $\mathrm{p} \leq 0.05$.

Якщо отримані дані перенести у діаграму, то помітно, що у групі 2 кількість підтвердженої катетер-асоційованої інфекції більша ніж у групі 1 та становить 18 , у той час як у групі 1-9. Кількість верифікованих випадків катетер-асоційованої інфекції сечових шляхів на 5-й день у групі 1 становила 18, у групі 2-30 (рис. 4). 
Таблиця 5

Частота виникнення катетер-асоційованих інфекцій сечових шляхів у дітей, шо потребують інтенсивної терапії (n=98)

\begin{tabular}{|c|c|c|c|}
\hline \multirow{2}{*}{$\begin{array}{c}\text { Час забору сечі для } \\
\text { мікробіологічного посіву }\end{array}$} & \multicolumn{2}{|c|}{ Частота виникнення бактеріоурії у \% } & \multirow{2}{*}{ p } \\
\cline { 2 - 3 } & Група 1 ( n=49) & Група 2 (n=49) & \\
\hline 3-й день & $18,37 \%$ & $36,73 \%$ & 0,04 \\
\hline 5-й день & $36,73 \%$ & $61,22 \%$ & 0,02 \\
\hline
\end{tabular}

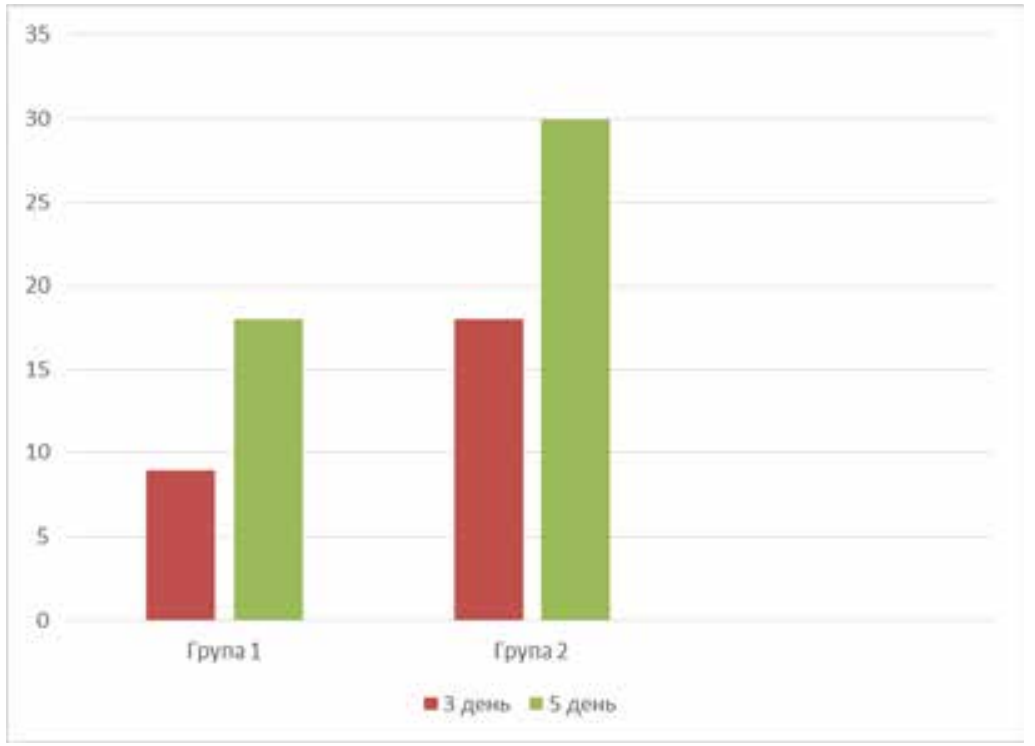

Рис. 4. Залежність частоти винекнення КАІСШ від умов катетеризації сечового міхура у паціснтів ВIT дитячої клініки (n=98) p $\leq \mathbf{0 . 0 5}$

\section{5. Аналіз якості життя у дітей з КАІСШ}

В останнє десятиліття поняття «якість життя» (ЯЖ) стало невід'ємною частиною системи охорони здоров'я та клінічних, медико-соціальних досліджень. Поступова заміна біомедичної моделі здоров'я на біопсихосоціальну модель, спричинила потребу у врахуванні суб'єктивного сприйняття людиною свого благополуччя [11, р. 850]. 
У 1982 році Kaplan і Вush запровадили термін «health-related guality of life» (якість життя пов'язана із здоров'ям), що дозволило виділити параметри котрі описують стан здоров'я, турботу про нього та якість медичної допомоги із загальної концепції ЯЖ.

ВООЗ були розроблені основні критерії ЯЖ: фізичні, психологічні, рівень самостійності, суспільне життя, довкілля і духовність [10, p. 899].

Залежно від галузі використання питальники ділять на групи: загальні питальники (використовуються як у здорових, так і у хворих дітей) та спеціальні питальники (специфічні для певного захворювання та патологічного стану).

Нами перекладений і адаптований опитувальник для визначення якості життя дітей віком 8-12 років Pediatric Quality of Life Inventory 2014.

У нашому дослідженні ми використовували лише опитувальник для дітей, оскільки доведено, що результати опитувальників для батьків дають менш об'єктивні результати і рекомендуються до використання лише тоді, коли немає можливості якісно проанкетувати дитину $[9$, p. 508].

Нами було набрано 80 пацієнтів, котрих поділено на 4 групи, співвідношення хлопчиків та дівчаток рівне. Групу 1 складали пацієнти 3 катетеризованим сечовим міхуром та інфекцією сечових шляхів, кількість пацієнтів 20. Група 2 складалась 3 пацієнтів із катетеризованим сечовим міхуром, але без інфекції сечових шляхів, кількістю 20 осіб. В групу 3 входили пацієнти без сечового катетера, з інфекцією сечових шляхів, у кількості 20. У групу 4 входили пацієнти без сечового катетера і без інфекції сечових шляхів, також у кількості 20.

За результатами анкетування, ми порівняли усі чотири аспекти життя дітей і отримали такий результат: сумарний бал у всіх чотирьох групах був не високим $(25,8 \pm 7,8$ група1, 26,6 \pm 6,7 група 2, 29,6 \pm 9,7 група 3, 30,4 \pm 8,3 група 4) (табл. 6).

Якщо отримані дані по складових психологічного стану (емоційне функціонування, соціальне життя, шкільна діяльність), перенести у діаграму, то помітно, що три складові психологічного функціонування однаково низький бал мають у всіх чотирьох групах (рис. 5).

Ми порівняли оцінку якості життя дітей за психологічним та фізичним функціонуванням і отримали наступний результат: якість життя за 
Таблиця 6

\section{Порівняння якості життя}

за усіма оцінюваними аспектами функціонування

\begin{tabular}{|l|c|c|c|c|}
\hline \multicolumn{1}{|c|}{ Аспекти якості життя } & $\begin{array}{c}\text { Група 1 } \\
\text { (n=20) }\end{array}$ & $\begin{array}{c}\text { Група 2 } \\
\text { (n=20) }\end{array}$ & $\begin{array}{c}\text { Група 3 } \\
\text { (n=20) }\end{array}$ & $\begin{array}{c}\text { Група 4 } \\
\text { (n=20) }\end{array}$ \\
\hline Емоційне функціонування & $17,3 \pm 6,7$ & $18,8 \pm 2,5$ & $25,5 \pm 2,8$ & $27,3 \pm 3,0$ \\
\hline Соціальне життя & $27,8 \pm 6,3$ & $28,5 \pm 6,3$ & $28,8 \pm 7,9$ & $28,8 \pm 9,4$ \\
\hline Шкільна діяльність & $18,5 \pm 2,2$ & $19,5 \pm 2,4$ & $25,0 \pm 2,3$ & $26,5 \pm 2,4$ \\
\hline Психологічний стан & $21,2 \pm 6,7$ & $22,3 \pm 5,9$ & $26,4 \pm 8,3$ & $27,5 \pm 7,9$ \\
\hline Фізичне функціонування & $34,5 \pm 11,7$ & $34,8 \pm 10,7$ & $35,5 \pm 7,1$ & $35,8 \pm 9,5$ \\
\hline Сумарний бал & $25,8 \pm 7,8$ & $26,6 \pm 6,7$ & $29,6 \pm 9,7$ & $30,4 \pm 8,3$ \\
\hline
\end{tabular}

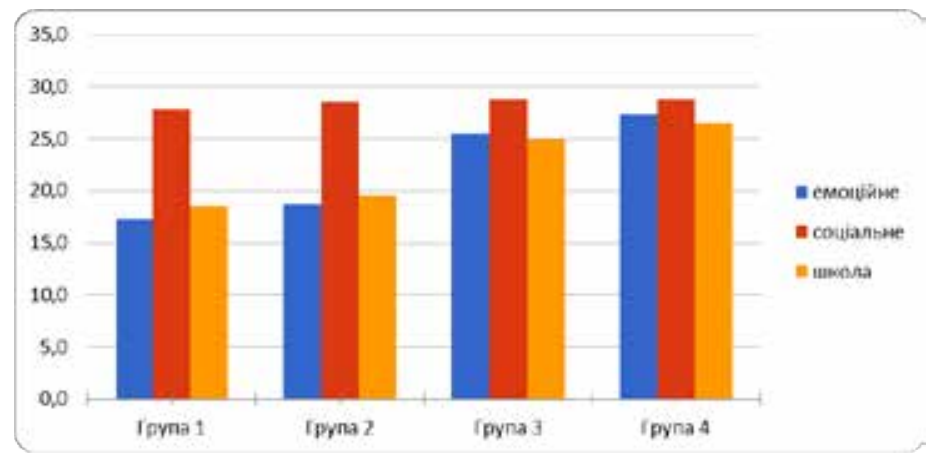

Рис. 5. Порівняння якості життя у дітей за складовими психологічного функціонування

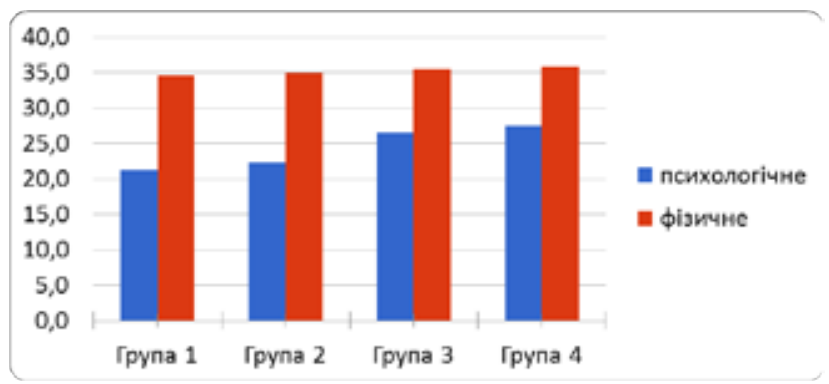

Рис. 6. Порівняльна характеристика якості життя у дітей за психічним та фізичним функціонуванням 
психологічним функціонуванням (21 - група 1, 22 - група 2, 29 - група 3 , 30 - група 4) була суттєво нижчою ніж за бал фізичного функціонування (34,5; 34,8; 35,5; 35,8 відповідно) у всіх чотирьох групах (рис. 6).

\section{6. Лікування}

За результатами нашого дослідження, ми розробили схему лікування катетер-асоційованих інфекцій сечових шляхів у дітей, що потребують інтенсивної терапії. Дана схема орієнтована на пацієнтів, що не мають патології сечової системи. Підозрюємо катетер-асоційовану інфекцію сечових шляхів, якщо катетер стоїть довше 48 годин. На третю добу катетеризації оцінюємо наступні фактори: скарги на біль в ділянці сечових шляхів; бактеріоурію, лейкоцитурію, епітелій сечі, слиз та прозорість сечі; анемія; лейкоцитопенія. Якщо є 2 і більше 3 вище перерахованих ознак ми видаляємо/замінюємо сечовий катетер i на наступний день повторно оцінюємо симптоми. Якщо симптоми регресували - то продовжуємо планову терапію. Коли симптоми не зникли - призначаємо бактеріологічний посів, антибактеріальну терапію розпочинаємо лише після результатів бактеріологічного посіву сечі (це зменшує частоту необгрунтованої антибіотикотерапії).

При виборі антибактеріального препарату орієнтуємось на результати бактеріологічного посіву, наказ МО3 УКРАЇНИ № 624 від 03.11.2008 «Про затвердження протоколу лікування дітей з інфекціями сечової систкеми і туболоінтерстиціальним нефритом», оновлені у 2012 році рекомендації Європейської асоціації урологів щодо діагностики та лікування інфекцй сечових шляхів у дітей та рекомендації Американської асоціації педіатрів (ААР, 2011).

У пацієнтів 3 алергією до цефалоспоринів може бути використаний азтреонам. Якщо є підозра на наявність грампозитивної флори, доцільне застосування ампіциліну або амоксициліну + клавуланова кислота. Хлорамфеніколу, сульфонамідів, тетрацикліну, рифампіцину, амфотерицину В і фторхінолонів треба уникати. Використання цефтріаксону також слід уникати у зв'язку з його небажаною побічною дією на жовчовиділення. Терапія ципрофлоксацином розглядається як другийтретій вибір, доза - 20-30 мг/кг/добу за три введення в/в або два - перорально.

При успішному лікуванні сеча зазвичай стає стерильною через 24 години, а лейкоцитурія зазвичай зникає протягом 3-4 днів. Норма- 
лізації температури тіла можна очікувати протягом 24-48 годин після початку терапії в 90\% випадків. У пацієнтів із тривалою лихоманкою і за відсутності нормалізації аналізів сечі та стану, а також у лікуванні резистентних або обструктивних процесів рекомендується проведення додаткових обстежень (у спеціалізованих відділеннях).

Для вагітних підлітків препаратами вибору є цефалоспорини II-Ш генерації, захищені амінопеніциліни, макроліди, (до 7 діб). Тривалість лікування - 10-14 діб.

Окрім того, виділяють антибактеріальні препарати резерву - карбапенеми (іміпенем, меропенем), уреїдопеніциліни (тикарцилін/клавунат, піперацилін/тазобактам), глікопептиди (ванкоміцин, таргоцид). При супутній урогенітальній інфекції використовуються відповідні препарати - орнідазол (тіберал), нітроімідазоли (наксоджин), макроліди (роксітроміцин, азітроміцин, джозаміцин, кларітроміцин).

\section{7. Висновки}

1. За результатами нашого дослідження, в етіологічній структурі катетер-асоційованих інфекцій сечових шляхів у дітей переважала монокультура (85,42\%). Видовий склад мікроорганізмів, що слугували зудниками КАІСШ наступний: Escherichia coli, Klebsiella pneumoniae, Enterococcus spp., Pseudomonas aeruginosa, Candida albicans, Staphylococcus epidermidis.

2. Статистично значущої у етіологічній структурі між хірургічним та соматичними пацієнтами відділення інтенсивної терапії ми не виявили.

3. Результати нашого дослідження показали, що грампозитивні збудники катетер-асоційованих інфекцій сечових шляхів були найбільш чутливими до імепенему, меронему, цефепіму, ванкоміцину. Грамнегативні збудники КАІСШ найбільш чутливі до імепенему та меронему. Загалом, наше дослідження показує високу та зростаючу антиботикорезистентність збудників катетер-асоційованих інфекцій сечових шляхів, що перебувають у відділенні інтенсивної терапії.

4. У пацієнтів котрим катетеризацію сечового міхура проводили в умовах операційної, ознаки інфекції сечових шляхів розвиваються 3 меншою частотою та швидкістю, у порівнянні з пацієнтами котрим катетеризація сечового міхура проводилась у відділенні інтенсивної терапії.

5. На нашу думку, розпочинати антибактеріальну терапію катетер-асоційованої інфекції сечових шляхів швидше третьої доби катете- 
ризації сечового міхура і до отримання результатів бактеріологічного дослідження сечі є недоцільним і підвищує антибіотикорезистентність мікроорганізмів відділення інтенсивної терапії.

6. На якість життя у дітей з катетеризованим сечовим міхуром, впливає більшою мірою психологічна травма та дискомфорт, ніж об'єм та кількість медичних маніпуляцій, що помітно за суттєво нижчими балами оцінки психічного функціонування у порівнянні з фізичним функціонуванням.

\section{References:}

1. Dudeck M.A., Edwards J.R., Allen-Bridson K., et al. (2015). National Healthcare Safety Network report, data summary for Device-associated Module. Am J Infect Control, 43: 206-221.

2. Rosenthal V.D., Al-Abdely H.M., El-Kholy A.A., et al. (2016). International Nosocomial Infection Control Consortium report, data summary of 50 countries for 2010-2015: device-associated module. Am J Infect Control, 44: 1495-1504.

3. Lewis S.S., Knelson L.P., Moehring R.W., et al. (2013). Comparison of nonintensive care unit (ICU) versus ICU rates of catheter-associated urinary tract infection in community hospitals. Infect Control Hosp Epidemiol, 34: 744-747.

4. Chant C., Smith O.M., Marshall J.C., Friedrich J.O. (2011). Relationship of catheterassociated urinary tract infection to mortality and length of stay in critically ill patients: a systematic review and meta-analysis of observational studies. Crit Care Med, 39: 1167-1173.

5. Tandogdu Z., Wagenlehner F.M. (2016). Global epidemiology of urinary tract infections. Curr Opin Infect Dis, 29: 73-79.

6. Lam T.B., Omar M.I., Fisher E., et al. (2014). Types of indwelling urethral catheters for short-term catheterisation in hospitalised adults. Cochrane Database Syst Rev, (9): Cd004013.

7. Mullin K.M., Kovacs C.S., Fatica C., et al. (2017). A multifaceted approach to reduction of catheter-associated urinary tract infections in the intensive care unit with an emphasis on 'stewardship of culturing'. Infect Control Hosp Epidemiol, 38: 186-188.

8. LaRocco M.T., Franek J., Leibach E.K., et al. (2016). Effectiveness of preanalytic practices on contamination and diagnostic accuracy of urine cultures: a laboratory medicine best practices systematic review and meta-analysis. Clin Microbiol Rev, 29: 105-147.

9. Wysocki T., Gavin L. (2006). Paternal involvement in the management of pediatric chronic diseases: associations with adherence, quality of life, and health status. J. Pediatr. Psychol, 31(5): 501-511.

10.Upton P. (2008). Parent-child agreement across child health-related quality of life instruments: a review of the literature. Qual Life Res, 17(6): 895-913.

11.Varni J.W. (2009). The pediatric quality of life inventory: measuring pediatric health-related quality of life from the perspective of children and their parents. Pediatr. Clin. North. Am., 56(4): 843-863. 